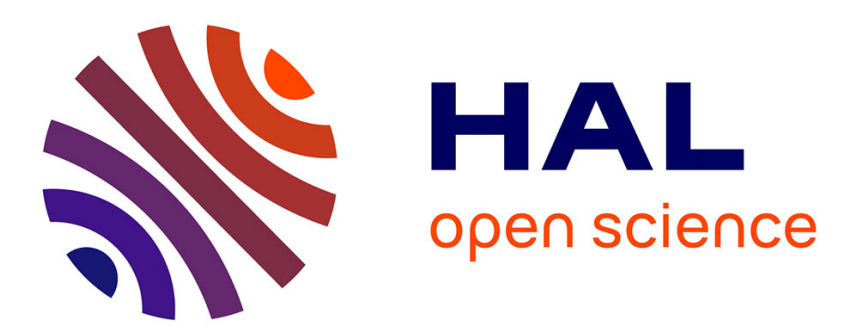

\title{
Soil fauna and site assessment in beech stands of the Belgian Ardennes
}

Jean-François Ponge, Pierre Arpin, Francis Sondag, Ferdinand Delecour

\section{To cite this version:}

Jean-François Ponge, Pierre Arpin, Francis Sondag, Ferdinand Delecour. Soil fauna and site assessment in beech stands of the Belgian Ardennes. Canadian Journal of Forest Research, 1997, 27 (12), pp.2053-2064. 10.1139/cjfr-27-12-2053 . hal-00505482

\section{HAL Id: hal-00505482 \\ https://hal.science/hal-00505482}

Submitted on 23 Jul 2010

HAL is a multi-disciplinary open access archive for the deposit and dissemination of scientific research documents, whether they are published or not. The documents may come from teaching and research institutions in France or abroad, or from public or private research centers.
L'archive ouverte pluridisciplinaire HAL, est destinée au dépôt et à la diffusion de documents scientifiques de niveau recherche, publiés ou non, émanant des établissements d'enseignement et de recherche français ou étrangers, des laboratoires publics ou privés. 
PONGE

1

2

3

4

5

$6{ }^{1}$ Author to whom all correspondence should be addressed. Museum National d'Histoire Naturelle,

\section{SOIL FAUNA AND SITE ASSESSMENT IN BEECH STANDS OF THE BELGIAN ARDENNES}

Jean-François Ponge ${ }^{1}$, Pierre Arpin ${ }^{2}$, Francis Sondag ${ }^{3}$ and Ferdinand Delecour ${ }^{4}$

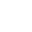

8

9

10

11

12

13

14

15

16

17

18

19 20

21 Laboratoire d’Ecologie Générale, 4 avenue du Petit-Chateau, 91800 Brunoy, France.

Phone number: +33160479213

Fax number: +33 160465009

E-mail: Jean-Francois.Ponge@wanadoo.fr

${ }^{2}$ Museum National d'Histoire Naturelle, Laboratoire d'Ecologie Générale, 4 avenue du Petit-Chateau, 91800 Brunoy, France.

${ }^{3}$ ORSTOM, Centre d'lle-de-France, Laboratoire des Formations Superficielles, 32 Avenue HenriVaragnat, 93143 Bondy Cedex, France.

${ }^{4}$ Faculté des Sciences Agronomiques de Gembloux, Science du Sol, avenue Maréchal-Juin 27, 5030 Gembloux, Belgium. Present address: Chaussée de Charleroi 97, 5030 Gembloux, Belgium. 
PONGE

1 Abstract: Soil fauna (macrofauna and mesofauna) were sampled in thirteen beech forest stands of the Ardenne mountains (Belgium) covering a wide range of acidic humus forms. The composition of soil fauna was well-correlated not only with humus form, but also with elevation, phytosociological type, tree growth, mineral content of leaf litter and a few soil parameters such as $\mathrm{pH}$ and $\mathrm{C} / \mathrm{N}$ ratio. The nature of mechanisms which can explain these relationships is discussed under the light of existing knowledge.

(1) $\left(\frac{100}{20}\right.$

Résumé: La faune du sol (macrofaune et mésofaune) a été échantillonnée dans treize peuplements de hêtre des Ardennes belges, couvrant une gamme étendue de formes d'humus acides. La composition faunistique est bien corrélée, non seulement avec la forme d'humus, mais aussi avec l'altitude, le groupement phytosociologique, la croissance des arbres, la composition minérale de la litière de feuilles et quelques paramètres édaphiques tels que le $\mathrm{pH}$ et le rapport $\mathrm{C} / \mathrm{N}$. La nature des mécanismes pouvant expliquer ces relations est discutée, à la lueur des connaissances actuelles.

\section{Introduction}

The assessment of site quality for the growth of forest stands has been based mainly on ground vegetation (Rodenkirchen 1985) and soil features (Turvey and Smethurst 1985). When the soil type does not change heavily, it has been observed that strong discrepancies in forest productivity may be explained by the rate at which litter disappears from the ground surface (Delecour 1978). This rate, expressed by a coefficient calculated first by Jenny et al. (1949), was proposed as a site factor for European beech (Fagus sylvatica L.) forests by Delecour and Weissen (1981).

The disappearance of canopy litter from the ground surface (improperly called decomposition) is strongly associated to humus form, i.e. moder and moreover mor humus are characterized by a slower rate of disappearance of leaf litter than mull humus (Van der Drift 1963). This phenomenon has been found to result from the consumption of litter by fauna and microflora, which vary in quantity and quality from a site to another (Toutain 1987; Schaefer and Schauermann 1990; Muys and Lust 1992). 
PONGE

We contrasted soil macro- and mesofauna with other site factors in 13 beech forests of the Belgian Ardennes, which share the same parent rock and regional climate but strongly differ by their productivity and humus form. In a previous paper (David et al. 1993) we characterized mull humus by a higher diversity of macrofaunal groups when compared to moder humus. Nevertheless the discriminative power of macrofauna was poor in the moder group (from hemimoder to dysmoder), where elaterid larvae (Insecta, Coleoptera) were one of the few macrofaunal taxa present. We hypothesized that a more complete study of soil fauna could allow to better discriminate these sites.

\section{Study sites}

The sites were thirteen beech (Fagus sylvatica) forest stands made of full-grown trees, where soils and plant communities had been previously studied in relation with forest productivity (Manil et al. 1953, 1963; Dagnelie 1956a, 1956b, 1957). They are typical of the forest cover of the Ardenne mountains. The climate shares atlantic and mountain features, being characterized by abrupt changes in temperature, with a mean annual temperature of $7.2^{\circ} \mathrm{C}$ and a mean annual rainfall ranging from 1000 to $1400 \mathrm{~mm}$ according to geographical location. These old Hercynian mountains have been strongly eroded, culminating at $694 \mathrm{~m}$ altitude. Rocks, ranging from Cambrian to Devonian age, are poor in bases (schists, graywackes, quartzites). Phytosociological and soil types are given in Table 1, together with elevation and geographical location.

\section{Material and methods}

\section{Soil fauna}

Macrofauna was sampled by forcing a $30 \times 30 \mathrm{~cm}$ steel frame into the litter sensu lato and the first $5 \mathrm{~cm}$ of underlying soil. Three samples were taken in each site in June 1989, then three others in October 1989. Samples were placed in plastic bags then transported to the laboratory. Animals were extracted 
PONGE

within 15 days by the dry-funnel method. For soil-dwelling earthworms an additional sampling around the same plots was done by watering a $50 \times 50 \mathrm{~cm}$ area three times at $10^{\prime}$ intervals with diluted formaldehyde as a repellent $(2,3$ then $4 \% \mathrm{v} / \mathrm{v})$, then digging the soil underneath down to $30 \mathrm{~cm}$. (1)

Mesofauna was sampled by forcing a $5 \mathrm{~cm}$ diameter steel cylinder into the top $15 \mathrm{~cm}$ of soil (litter included), at the same dates as for macrofauna, but with only $2 \times 2$ replicates. Samples were then (1)

Given the poor efficiency of the dry-funnel method for enchytraeid worms, these animals, together with other visible soil animals, were hand-sorted directly in special soil cores $(5 \times 5 \times 15 \mathrm{~cm})$ which were taken in June 1989 for micromorphological purposes (2 replicates in each site), according to the method described by Ponge (1991). Hand-sorting was performed by dividing the cores into small volumes of litter and soil which were observed into ethyl alcohol under a dissecting microscope. Plant fragments as well as soil aggregates were thoroughly comminuted and all mesofauna and macrofauna were recovered, thus allowing comparisons with extraction methods.

Table 2 indicates the animal groups which were identified and counted, together with the methods used for their recovery.

\section{Litter accumulation}

The surface weight of litter layers, estimated just after main leaf fall, was used to compare the different sites. The $\mathrm{O}$ horizon, i.e. the pure or near pure organic matter accumulated at the top of the soil profile (Delecour 1980; Brêthes et al. 1995; Jabiol et al. 1995) can be divided into several horizons called OL (entire leaves), OF (fragmented leaves) and $\mathrm{OH}$ (holorganic faecal material). These horizons are called $L, F$, and $H$, respectively, in the classification of Green et al. (1993), which assigns the term O horizon to wetland soils, only. The more rapid is the disappearance of litter from the ground, the less important are $\mathrm{OF}$ and $\mathrm{OH}$ horizons compared to $\mathrm{OL}$ horizon, which at the end of autumn is mainly made of freshly fallen litter. We calculated the litter accumulation index (LAI) as the ratio $\mathrm{W}_{\mathrm{OF}+\mathrm{OH}} / \mathrm{W}_{\mathrm{OL}}$, where $\mathrm{W}_{\mathrm{OF}+\mathrm{OH}}$ and $\mathrm{W}_{\mathrm{OL}}$ are the areal weights of $\mathrm{OF}+\mathrm{OH}$ and $\mathrm{OL}$ horizons, respectively. For that purpose, these horizons were sampled in the study sites at the end of November 1989 , by forcing six $15 \mathrm{~cm}$ 
PONGE

1

diameter stainless steel cylinders through the topsoil. Samples were transported to the laboratory then dried in air-forced chambers at constant temperature $\left(25^{\circ} \mathrm{C}\right)$ during a fortnight, before being weighed to the nearest $10^{-2} \mathrm{~g}$. After this step, beech leaves were sorted and weighed separately, in the OL horizon only.

\section{Stand productivity}

Following previous work on the same sites (Dagnelie 1956a, 1956b, 1957), a linear relationship was demonstrated between the mean total height of co-dominant trees and the mean annual increment of wood available for timber production. For instance total heights of 25,30 , and $35 \mathrm{~m}$ were associated with increments of 3.6, 5.4, and $7.4 \mathrm{~m}^{3} \cdot \mathrm{ha}^{-1} \cdot \mathrm{yr}^{-1}$, respectively. Thus we used total height of adult codominant trees as a productivity index. This height was mesured on six co-dominant trees growing in the vicinity of the sampling plot. In some cases (sites $1,5,100)$ a lower number of individuals $(3,3,2$, respectively) was used, due to the smaller size of the study site or timber harvesting during previous years. The total height of each selected tree was measured with a Suunto Hypsometer ${ }^{\circledR}$ compass to the nearest $1 / 4 \mathrm{~m}$.

\section{Litter chemical analyses}

Beech leaf litter and miscellaneous litter were separately analysed in the OL samples used for the determination of the litter accumulation index. For that purpose samples from the same site were bulked into a composite sample which was ground then dried overnight at $103^{\circ} \mathrm{C}$, in order to determine its dry mass. The ash content was measured by calcinating $1 \mathrm{~g}$ of powdered dry litter in a muffle furnace at $550^{\circ} \mathrm{C}$ for $5 \mathrm{~h}$. Total nitrogen was quantified by Kjeldahl digestion into a Kjeltec® autoanalyser on a separate $200 \mathrm{mg}$ sub-sample. Total carbon was quantified by the Anstett method, using concentrated sulfuric acid and potassium bichromate as oxydants and Mohr salts for titration, on a $100 \mathrm{mg}$ sub-sample. Other elements $(\mathrm{Ca}, \mathrm{Mg}, \mathrm{K}, \mathrm{P}, \mathrm{Fe})$ were determined by high frequency plasma emission photometry on the ashed sub-sample after dissolution in hydrochloric acid and elimination of silica by hydrofluoric acid.

\section{Humus form}


PONGE

2 Humus form was identified in each sampling plot in June 1989 while taking samples for micromorphological studies (two replicates in each site). Nomenclature was derived from Brêthes et al. (1995). According to this classification the O horizon (litter sensu lato) and the A horizon (organo-

\section{Soil chemical analyses}

These analyses were performed separately on 6 replicate samples taken in each site after collection of the $\mathrm{O}$ horizon as abovementioned. The underlying $\mathrm{A}$ horizon was collected down to $5 \mathrm{~cm}$ depth under the bottom of the $O$ horizon, then air-dried until analysis. Samples were sieved $(<2 \mathrm{~mm})$ then homogenized. Water $\mathrm{pH}$ and potassium chloride $\mathrm{pH}$ were measured on a $5 \mathrm{~g}$ sub-sample diluted with deionized water (soil:water 1:1 w/w). A $50 \mathrm{~g}$ sub-sample was crushed with pestle and mortar, then sieved $(<200 \mu \mathrm{m})$ for further analyses. Cation exchange capacity was measured on a $10 \mathrm{~g}$ sub-sample by percolating the soil with $1 \mathrm{~N}$ calcium chloride until saturation of exchange sites then displacing calcium with $1 \mathrm{~N}$ potassium nitrate. Determination of calcium and chloride content was performed in the filtrate by flame nitrous oxyde-acetylene atomic absorption photometry, and complexometry with a Technicon $\AA$ autoanalyser, respectively. Exchangeable cations $(\mathrm{Ca}, \mathrm{Mg}, \mathrm{K}, \mathrm{Na})$ were determined on a $10 \mathrm{~g}$ sub-sample after displacement of sorbed cations with ammonium nitrate. Potassium and sodium were determined on the filtrate by flame emission photometry, calcium and magnesium by flame atomic absorption photometry. Total carbon and nitrogen were determined with a $\mathrm{CHN}$ Carlo Erba ${ }^{\circledR}$ analyser on a $5 \mathrm{mg}$ sub-sample. Total bases $(\mathrm{Ca}, \mathrm{Mg}, \mathrm{K}, \mathrm{Na})$, iron and manganese were determined on $1 \mathrm{~g}$ sub-sample after boiling with concentrated hydrochloric acid. Potassium and sodium were determined by flame air-acetylene emission photometry, magnesium, iron and manganese by flame air-acetylene atomic absorption photometry, and calcium by flame nitrous oxyde-acetylene atomic absorption photometry. Total phosphorus was determined on a $1 \mathrm{~g}$ sub-sample with a Techicon ${ }^{\circledR}$ autoanalyser after treatment with concentrated hydrogen peroxyde followed by boiling with perchloric acid. 
PONGE

\section{Data analysis}

Effects of season or extraction methods on animal densities were tested by means of two-way ANOVA using sites as blocks (Sokal and Rohlf 1995; Rohlf and Sokal 1995). In order to ensure additivity of variance data were previously transformed into $\log (x+1)$. All means given for each site were calculated using log-transformed data.

Sites were ordinated according to their faunal composition by help of correspondence analysis (Greenacre 1984). Active variates were mean densities of the different animal groups in the 13 studied sites. Data were reweighted to a unit standard deviation and focused around a mean of 10 by using the transformation $\mathrm{x} \rightarrow(\mathrm{x}-\mathrm{m}) / \mathrm{s}+10$, where $\mathrm{m}$ is the mean and $\mathrm{s}$ is the standard deviation for each variate, respectively. By this way the different animal groups have a similar mass and similar total variance, thus allowing factorial coordinates to be directly interpreted in terms of their contribution to factorial axes. Each variate was associated with a conjugate, varying in an opposite sense $\left(x^{\prime}=20-x\right)$. Thus each animal group will be represented by two points, one indicating higher densities for this group, the other lower densities. Passive variates, describing environmental conditions, were added, in order to measure their degree of relationship with this ordination, which was based on faunal composition only. Passive data were reweighted and focused in a similar way. Correlation coefficients between factorial axes and variates or between variates were calculated on transformed data according to the productmoment formula of Pearson and were tested by the t-test method (Sokal and Rohlf 1995).

\section{Results}

\section{Choice of methods for recovering animals}

Most macrofaunal groups were sampled on a much wider surface than mesofauna, given lower density and patchiness of these animals in the soil (Macfadyen 1957). Enchytraeid worms were recovered by dissecting litter and humus samples at a high magnification. This was also the case for copepods, 
PONGE

1 phthiracarid mites, miscellaneous mites, pauropods, Symphyla, Protura, cecidomyid, ceratopogonid, 2 chironomid, sciarid, miscellaneous fly larvae, cochineals, and booklice. In all these cases the 3 advantage of direct counting against active extraction of animals was evident, thus we judged preferable to chose the first method, despite the poorer number of replicates (2, against 4 for active extraction of mesofauna). For miscellaneous oribatid mites and springtails, which were collected in high numbers both by dry funnels and by direct counting, an ANOVA was performed on June samples (2 replicates for each method in each of the 13 sites). Extraction by the dry-funnel method furnished more animals than direct counting for oribatid mites $(p<0.0001)$, but differences between methods were insignificant for springtails $(p=0.17)$. The methods chosen for the different animal groups are indicated in Table 2.

\section{Seasonal influences}

Densities of three macrofaunal groups were significantly affected by season, with more animals in November than in June, i.e. spiders, adult beetles, and pseudoscorpions, with $p=0.003,0.03$, and $p<0.0001$, respectively (two-way ANOVA). Only two mesofaunal groups were significantly affected, with more animals in June than in November, i.e. springtails and miscellaneous oribatid mites, with $p=$ 0.006 and 0.01 , respectively. Given that significant differences were few, we decided to pool the data from the two sampling periods into a composite mean for each study site.

\section{Ordination of sites according to faunal composition}

Correspondence analysis of faunal data helped to ordinate sites according to their faunal composition.

The first axis extracted $25 \%$ of the total variance. Examination of the position of sites and zoological groups along this axis (Fig. 1) and of faunal densities (Table 3) showed a progressive shift from macrofauna-dominated to enchytraeid-dominated sites, with the exception of some macrofaunal groups such as click-beetle larvae (CLIC), Diplura (DIPL) and cochineals (COCH). On the positive side of axis 1 only enchytraeid (ENCH) and click-beetle (CLIC) densities were significantly correlated with axis 1 coordinates. On the negative side limnobiid larvae (LIMN), scatopsid larvae (SCAT), dolichopodid-empidid larvae (DOEM), milliped (MILL), Trichoptera larvae (TRIC), cantharid larvae (CANT), woodlice (ISOP), earthworm (LUMB), pseudoscorpion (PSEU), rhagionid larvae (RHAG), 
PONGE

chironomid larvae (CHIR), mollusc (MOLL), and muscid larvae (FANN) densities, were all significantly correlated with axis 1 coordinates. All these groups were significantly correlated between them, indicating that the global trend depicted by axis 1 was a community gradient.

We may nevertheless question whether groups placed in an intermediate position, i.e. not far from the origin, i) do not vary to a great extent between sites, ii) are influenced by other factors than this community gradient, or iii) are more abundant in sites placed in an intermediary position (such as sites $3,17,22,24)$ than in sites placed far from the origin on the positive or on the negative side of axis 1. The case of groups such as ants (ANTS), copepods (COPE), earwigs (DERM), miscellaneous insect larvae (LMIS), psychodid larvae (PSYC), and booklice (PSOC) cannot be accounted for, since they are scarce and present in a low number of sites. On the contrary, oribatid mites (ORIB) and sciarid larvae (SCIA), placed not far from the origin, are abundant and present everywhere. The first group proved to be significantly more abundant in some sites than in others $(F=3.56$, d.f. $=12 / 39, p=$ 0.0013), the second group did not significantly differ between sites $(F=1.17$, d.f. $=12 / 13, p=0.39)$. Examination of the mean densities of Oribatid mites in the 13 sites (Table 3) showed that these animals were very abundant in sites located on both sides of axis 1 . Thus their distribution did not follow the global trend exhibited by the first axis of correspondence analysis (case ii). Sciarid larvae were rather evenly distributed (case i). We did not register the third postulated case, i.e. zoological groups characteristic of sites placed in an intermediary position by the analysis.

\section{Explanatory value of site features}

Elevation, together with phytosociological type and humus form, proved to discriminate the studied sites, ordinated according to axis 1 of correspondence analysis (Fig. 2, Table 4). Elevation was significantly and positively correlated with axis $1(r=0.65, p<0.05)$, thus increasing from site 100 to site 4. Along this community gradient humus form varied from dysmull to dysmoder, i.e. from rapid to slow disappearance of litter (Brêthes et al. 1995). Oligomull was undistinguishable from dysmull, and amphimull, hemimoder and eumoder were placed in an intermediary position, being undistinguishable from each other. The phytosociological type varied from Melico-Fagetum festucetosum, with a rich ground flora and highly productive, which is characteristic of lowland sites (Thill et al. 1988), to LuzuloFagetum vaccinietosum, much poorer in ground flora and weakly productive, which is mostly 
PONGE

1

established on tablelands and sunny slopes. Soil types did not express a good relationship with axis 1 , contrary to humus forms and phytosociological types.

(3)

Total height of co-dominant trees was significantly correlated with axis $1(r=-0.56, p<0.05)$, together with $\mathrm{pH} \mathrm{H}_{2} \mathrm{O}(\mathrm{r}=-0.75, \mathrm{p}<0.01), \mathrm{pH} \mathrm{KCl}(\mathrm{r}=-0.71, \mathrm{p}<0.01)$, and $\mathrm{C} / \mathrm{N}$ ratio of the $\mathrm{A}$ horizon $(\mathrm{r}=$ $0.88, p<0.01$ ). Thus the community gradient from site 100 to site 4 was characterized by a bulk decrease in the height of trees and soil $\mathrm{pH}$, and an increase in $\mathrm{C} / \mathrm{N}$ ratio (Fig. 3, Table 4). No significant correlation was found for axis 1 with the litter accumulation index (LAl) and surface weight of $\mathrm{OF}+\mathrm{OH}$ horizons.

Among total soil elements, only manganese was significantly correlated with axis $1(r=-0.87$, $\mathrm{p}<0.01$ ), its content in the top $5 \mathrm{~cm}$ of the A horizon decreasing from site 100 to site 4 (Fig. 4, Table 4). No significant correlation was found with cation exchange capacity nor exchangeable bases.

\section{The richness of litter in mineral matter (ash content) was significantly correlated with axis 1 , both} for total litter and beech leaf litter $(r=-0.86, p<0.01$ and $r=-0.77, p<0.01$, respectively), decreasing from site 100 to site 4 (Fig. 5, Table 4). At the elemental scale the same trend was depicted by iron, calcium and magnesium, both for total litter and beech leaf litter.

\section{Discussion}

The fauna of investigated sites was clearly varying in the same sense as soil fertility, this feature being expressed not only by $\mathrm{pH}$ and $\mathrm{C} / \mathrm{N}$ ratio of the $\mathrm{A}$ horizon (Brady 1984), but also by mineral richness of leaf litter (Mangenot and Toutain 1980) and tree growth (Dagnelie 1957). We may nevertheless ask to which extent the faunal composition was here determined by site conditions. The possibility of feedback loops between fauna and site conditions should not be overlooked, too, except for some features such as elevation which are not placed under biological control. 
PONGE

In the Belgian Ardennes, altitude has been locally considered as the most prominent regional factor influencing stand productivity, humus and phytosociological type (Dagnelie 1957; Manil et al. 1963; Delecour and Prince-Agbodjan 1975; Thill et al. 1988). Higher altitude means colder climate and higher precipitation, in a geographic zone (the Ardenne mountains) where the regional climate is harsher and more rainy than in any other part of Belgium (average annual temperature $7^{\circ} \mathrm{C}$, average annual rainfall $1100 \mathrm{~mm}$ ). This may have consequences on the level of biological activity, but also on the leaching of mineral elements during periods of low biological activity (winter), upland sites being thus impoverished compared to lowland sites. In addition, erosion progressively enriched lowland sites in nutrients at the expense of upland sites (Duchaufour 1995). Combined to climate effects of altitude (Manil et al. 1963), higher elevation (upland sites) means also harder parent rocks than along slopes (Thill et al. 1988) and even more than along rivers (lowland sites, the more typical being site 100, nutrients through differences in mineral weathering (Gaiffe and Bruckert 1990). Due to synergistic availability of mineral elements for organisms, when compared to lowland sites. animals is related to mineral richness of beech and total litter, sites with a mull fauna (negative side of axis 1) having richer beech and total litter than sites with a moder fauna (positive side of axis 1). It should be highlighted that this effect of litter richness concerns more metals (iron) and alkaline earths (calcium, magnesium) than main nutrients such as nitrogen, potassium, and phosphorus, or the $\mathrm{C} / \mathrm{N}$ ratio, contrary to literature data on plant litter decomposition (Melillo et al. 1982) and palatibility of leaf litter to saprophagous animals (Hendriksen 1990). The high calcium requirements of most earthworm (Piearce 1972), milliped (Reichle et al. 1969; Carter and Cragg 1976) and woodlice (Krivolutzky and Pokarzhevsky 1977) species, all typical of the negative side of axis 1 (mull side) may nevertheless explain the absence of these groups in sites with a poorer Ca content of litter (moder side). But here possible feed-back loop effects, which reinforce this selective process, must be considered, i) through the cycling of mineral elements by fauna, ii) through the phenolic content of beech foliage. Woodlice, millipeds and earthworms have been consistently demonstrated to increase the leaching of nutrients from decaying leaf litter (Anderson et al. 1983; Morgan et al. 1989), thus increasing their availability to 
PONGE

1 the structure of soil animal communities determined the extent of $\mathrm{N}$ mineralization. Thus the availability

2 of mineral elements for vegetation may be increased or decreased according to composition of the soil

3 fauna (Scheu and Parkinson 1994). This in turn may affect the mineral composition of the beech foliage (Toutain and Duchaufour 1970). The phenolic content of tree foliage has been demonstrated to influence the palatibility of leaves to earthworms (Satchell and Lowe 1967), a lower content in phenolics being associated with higher palatability. Thus the phenolic content of litter may affect directly some animal groups through their food preferences. It also determines soil-forming and microbial processes, a higher phenolic content of tree foliage and litter increasing the leaching of bases during periods of low biological activity and making proteins harder to decay through complexing processes (Davies 1971). Conversely the production of phenolics and other secondary plant metabolites increases in nutrient-poor conditions (Kuiters 1990), thus self-reinforcing the process.

We can now examine the influence of soil chemistry and humus form on soil animals, and its counterpart, their influence on these conditions. Observations on the distribution of soil animals in varying site conditions proved that, beside considerable variation from species to species, some zoological groups in bulk are seemingly correlated with soil and humus properties. Less acid soils, with mull humus forms, were found to be characterized by a richer and more abundant saprophagous macrofauna, especially earthworms, molluscs, woodlice and millipeds (Bornebusch 1930; Van der Drift 1962; Abrahamsen 1972b; Petersen and Luxton 1982; David 1987; Herlitzius 1987; Staaf 1987; Schaefer and Schauermann 1990; Schaefer 1991; Ponge and Delhaye 1995), like in the present study. The abovementioned association of chironomid fly larvae with mull humus (negative side of axis 1) has been already registered by Healey and Russel-Smith (1971). The association of Nematocera fly larvae families (Rhagionidae, Dolichopodidae, Empididae, Chironomidae, as representative in our samples) with less acid soils has been already established by Herlitzius (1987). In the case of enchytraeids, literature data indicate that species richness decreases when acidity increases and unincorporated organic matter accumulates (moder or mor humus), the opposite trend being observed with total abundance, due to dominance of Cognettia sphagnetorum in raw humus (Abrahamsen 1972a; Healy 1980; Petersen and Luxton 1982), thus confirming our results on this group as a whole. A similar phenomenon has been observed by Bornebusch (1930) on click-beetle (Elateridae) larvae in beech forests of Denmark, the density of Athous subfuscus increasing dramatically in raw humus (in fact dysmoder), which is confirmed by our observations on beech forests in Belgium (David et al. 1993). 
PONGE

The direct action of soil chemistry on soil animals is difficult to evidence, due to multiple interactions with trophic and habitat features, although it has been suspected following community studies (Ponge 1993; Healy 1980), and studies on the sensitivity of animals to acidity and osmolarity of soil solutions (Laverack 1961; Jaeger and Eisenbeis 1984; Heungens and Van Daele 1984). Experimental liming has been found detrimental to enchytraeid species living in acid conditions (Abrahamsen 1983; Huhta et al. 1986), the contrary being true for earthworms (Huhta 1979; Toutain et al. 1987; Robinson et al. 1992). These results should nevertheless be accepted with caution, because in the short term abrupt changes in soil conditions following lime (or acid) application act only on existing species. Results such as those of Robinson et al. (1992), Muys and Lust (1992) and Rundgren (1994), which in some sites did not evidence any increase in earthworm densities following liming, could be explained by the absence of acid-intolerant species in the vicinity of experimental sites. This introduces the problem of the time lapse needed for slow ecological processes such as the adaptation of communities to changing environmental conditions (Burges 1960). Results from synchronic studies on humus dynamics (Bernier and Ponge 1994) indicated that the course of shifts from moder to mull humus could be conditioned by the activity of some burrowing and acid-tolerant earthworm species such as Lumbricus terrestris. Other mull inhabitants may colonize the soil profile only several decades after it has begun to be transformed by this burrowing species. Thus the need for conditions prevailing in mull humus forms, expressed by a lot of saprophagous and even predaceous groups (pseudoscorpions, dolichopodid-empidid and rhagionid larvae), is probably the result of multiple interactions involving feeding, behavioural and physico-chemical requirements of soil animals.

The action of soil fauna on soil chemical properties is better known, mainly through their building of humus forms (Kubiëna 1955; Bal 1970; Hole 1981) and their abovementioned action on nutrient cycling. It has been experimentally verified that the introduction of lacking animal groups, without any further change in environmental conditions, may definitely change site quality (Bal 1982; Scheu and Parkinson 1994). These experiments concerned only the introduction of earthworm species, followed by the appearance of mull humus forms as the result of their burrowing activity. Here we may ask whether the appearance of dysmoder humus form (moder humus with a thick $\mathrm{OH}$ horizon) can be determined not only by the absence of zoological groups comprising litter-consuming and burrowing 
PONGE

amounts in sites placed on the positive side of axis 1 (Table 3). Enchytraeids have been suspected as having a detrimental influence not only on decomposition of organic matter (Wolters 1988) but also on earthworm populations (Haukka 1987) when they reach high densities. Conversely other authors found them contributing significantly to mineralization processes (Sulkava et al. 1996), thus giving a contrasted landscape concerning the role of these animals in litter decomposition and soil-forming processes.

(1)

(1)

9

(1)

his
humification processes (Ulrich 1986), thus they are as well causes as consequences of the building of humus forms. The manganese content of the topsoil, which is also involved in many biological processes, has been found associated with humus type, together with iron, being much higher in mull than in moder humus (Duchaufour and Rousseau 1959; Toutain and Védy 1975), and is, together with the $\mathrm{C} / \mathrm{N}$ ratio, highly correlated with vitality of forest trees (Van Straalen et al. 1988). Manganese, as well as iron, oxidizes phenolic acids, thus alleviating allelopathic and complexing processes due to small-molecule aromatic compounds (Lehmann et al. 1987).

If we try to synthesize all these relationships in a common scheme, the following hypothetical sequence can be considered as most realistic, at least in the present stage of our knowledge. Altitude, given the specificity of the studied zone (the Ardenne mountains), can be considered as determining a lot of site features which may drive the soil system towards one or the other of two poles: a mull pole, better expressed in lowland sites, with more animal groups, especially saprophagous macrofauna, and better growth of trees, and a dysmoder pole, better expressed in upland sites, with fewer animal groups, mostly enchytraeids, and poorer growth of trees. Mechanisms of the action of site conditions upon soil fauna (and the reverse) may involve in first the content of leaf litter in metals and alkaline earths, which proved better correlated with faunal abundance and diversity than richness of the soil in these elements. If this hypothesis is true, then mull and dysmoder, stabilized by numerous feed-back loops involving vegetation, decomposers and humus profiles (Perry et al. 1989), should act as steadystate positions for ecological conditions prevailing in beech ecosystems of the Ardenne mountains. In this case the number of intermediate conditions should be less than expected if the sites had been 
PONGE

1

2

3

4

5

6

7

8

9

10

randomly scaled between these two poles. This may be observed along axis 1, where sites 1, 100 and 28 (mull pole) are clearly isolated from the rest of the sample. Unfortunately the total number of sites of the mull type was not high enough for testing properly the significance of this pattern over the whole range of investigated sites. (1)

\section{References} (1)

Abrahamsen, G. 1972a. Ecological study of Enchytraeidae (Oligochaeta) in Norwegian coniferous forest soils. Pedobiologia 12: 26-82.

Abrahamsen, G. 1972b. Ecological study of Lumbricidae (Oligochaeta) in Norwegian coniferous forest soils. Pedobiologia 12:267-281.

Abrahamsen, G. 1983. Effects of lime and artificial acid rain on the enchytraeid (Oligochaeta) fauna in coniferous forest. Holarct. Ecol. 6: 247-254.

Anderson, J.M., Ineson, P., and Huish, S.A. 1983. Nitrogen and cation mobilization by soil fauna feeding on leaf litter and soil organic matter from deciduous woodlands. Soil Biol. Biochem. 15: 463-467.

Bal, L. 1970. Morphological investigation in two moder-humus profiles and the role of the soil fauna in their genesis. Geoderma 4: 5-36.

Bal, L. 1982. Zoological ripening of soils. PUDOC, Wageningen, The Netherlands.

Bernier, N., and Ponge, J.F. 1994. Humus form dynamics during the sylvogenetic cycle in a mountain spruce forest. Soil Biol. Biochem. 26: 183-220.

Bornebusch, C.H. 1930. The fauna of forest soil. Forst. Forsøgsv. №11.

Brady, N.C. 1984. The nature and properties of soil, $9^{\text {th }}$ edition. Macmillan, New York, New York.

Brêthes, A., Brun, J.J., Jabiol, B., Ponge, J.F., and Toutain, F. 1995. Classification of forest humus forms: a French proposal. Ann. Sci. For. 52: 535-546.

Burges, A. 1960. Time and size as factors in ecology. J. Ecol. 48: 273-285.

Carter, A., and Cragg, J.B. 1976. Concentrations and standing crops of calcium, magnesium, potassium and sodium in soil and litter arthropods and their food in an aspen woodland ecosystem in the Rocky Mountains (Canada). Pedobiologia 16: 379-388. 
PONGE

Dagnelie, P. 1956a. Recherches sur la productivité des hêtraies d'Ardenne en relation avec les types phytosociologiques et les facteurs écologiques. I. Recherche d'un critère de station utilisable dans les hêtraies d'Ardenne. Bull. Inst. Agron. Stat. Rech. Gembloux 24: 249-284.

Dagnelie, P. 1956b. Recherches sur la productivité des hêtraies d'Ardenne en relation avec les types phytosociologiques et les facteurs écologiques. II. Utilisation d'un critère de station dans les hêtraies d'Ardenne. Bull. Inst. Agron. Stat. Rech. Gembloux 24: 369-410.

Dagnelie, P. 1957. Recherches sur la productivité des hêtraies d'Ardenne en relation avec les types phytosociologiques et les facteurs écologiques. III. Interprétation des résultats. Bull. Inst. Agron. Stat. Rech. Gembloux 25: 44-94.

David, J.F. 1987. Relations entre les peuplements de Diplopodes et les types d'humus en forêt d'Orléans. Rev. Ecol. Biol. Sol 24: 515-525.

David, J.F., Ponge, J.F., and Delecour, F. 1993. The saprophagous macrofauna of different types of humus in beech forests of the Ardenne (Belgium). Pedobiologia 37: 49-56.

Davies, R.I. 1971. Relation of polyphenols to decomposition of organic matter and to pedogenetic processes. Soil Sci. 111: 80-85.

Delecour, F. 1978. Facteurs édaphiques et productivité forestière. Pédologie 28: 271-284.

Delecour, F. 1980. Essai de classification pratique des humus. Pédologie 30: 225-241.

Delecour, F., and Weissen, F. 1981. Forest-litter decomposition rate as a site factor. Mittl. Forst. Bundesversuchsanst. Wien 140: 117-123.

Delecour, F., and Prince-Agbodjan, W. 1975. Etude de la matière organique dans une biotoposéquence de sols forestiers ardennais. I. Distribution du carbone et de l'azote dans les fractions humiques. Bull. Rech. Agron. Gembloux 10: 135-150.

Dindal, D.L. 1990. Soil biology guide. John Wiley and Sons, New York, New York.

Driessen, P.M., and Dudal, R. 1991. The major soils of the world. Agricultural University of Wageningen, The Netherlands, and Catholic University of Leuven, Belgium.

Duchaufour, P. 1995. Pédologie. Sol, végétation, environnement. Masson, Paris, France.

Duchaufour, P., and Rousseau, L.Z. 1959. Les phénomènes d'intoxication des plantules de résineux par le manganèse dans les humus forestiers. Rev. For. Fr. 11: 835-847. 
PONGE

Gaiffe, M., and Bruckert, S. 1990. Origine paléoécologique de l'aptitude des calcaires jurassiques à la fracturation. Conséquences tectoniques, pédogénétiques et écologiques. Bull. Soc. Neuchâtel. Sci. Nat. 113: $191-206+2$ inlet plates.

Green, R.N., Trowbridge, R.L., and Klinka, K. 1993. Towards a taxonomic classification of humus forms. For. Sci. Monogr. №29.

Greenacre, M.J. 1984. Theory and applications of correspondence analysis. Academic Press, London, United Kingdom.

Haimi, J., and Einbork, M. 1992. Effects of endogeic earthworms on soil processes and plant growth in coniferous forest soil. Biol. Fertil. Soils 13: 6-10.

Haukka, J.K. 1987. Growth and survival of Eisenia fetida (Sav.) (Oligochaeta: Lumbricidae) in relation to temperature, moisture and presence of Enchytraeus albidus (Henle) (Enchytraeidae). Biol. Fertil. Soils 3: 99-102.

Healey, I.N., and Russel-Smith, A. 1971. Abundance and feeding preferences of fly larvae in two woodland soils. In: Organismes du sol et production primaire, Proceedings of the $4^{\text {th }}$ Colloquium Pedobiologiae, Dijon, France, 14/IX-19/IX 1970. INRA, Paris, France. pp. 177-191.

Healy, B. 1980. Distribution of terrestrial Enchytraeidae in Ireland. Pedobiologia 20: 159-175.

Hendriksen, N.B. 1990. Leaf litter selection by detritivore and geophagous earthworms. Biol. Fert. Soils 10: $17-21$.

Herlitzius, H. 1987. Decomposition in five woodland soils: relationships with some invertebrate populations and with weather. Biol. Fertil. Soils 3: 85-89.

Heungens, A., and Van Daele, E. 1984. The influence of some acids, bases and salts on the mite and Collembola population of a pine litter substrate. Pedobiologia 27: 299-311.

Hole, F.D. 1981. Effects of animals on soil. Geoderma 25: 75-112.

Huhta, V. 1979. Effects of liming and deciduous litter on earthworm (Lumbricidae) populations of a spruce forest, with an inoculation experiment on Allolobophora caliginosa. Pedobiologia 19: 340-345.

Huhta, V., Hyvönen, R., Koskenniemi, A., Vilkamaa, P., Kaasalainen, P., and Sulander, M. 1986. Response of soil fauna to fertilization and manipulation of $\mathrm{pH}$ in coniferous forests. Acta For. Fenn. $\mathrm{N}^{\circ} 195$ 
PONGE

Jabiol, B., Brêthes, A., Ponge, J.F., Toutain, F., and Brun, J.J. 1995. L'humus sous toutes ses formes. ENGREF, Nancy, France.

Jaeger, G., and Eisenbeis, G. 1984. pH-dependent absorption of solutions by the ventral tube of Tomocerus flavescens (Tullberg, 1871) (Insecta, Collembola). Rev. Ecol. Biol. Sol 21: 519-531.

Jenny, H., Gessel, S.P., and Bingham, F.T. 1949. Comparative study of decomposition rates of organic matter in temperate and tropical regions. Soil Sci. 68: 419-432.

Krivolutzky, D.A., and Pokarzhevsky, A.D. 1977. The role of soil animals in nutrient cycling in forest and steppe. In: Soil organisms as components of ecosystems. Editors: U. Lohm and T. Persson. Ecol. Bull. 25: 253-260.

Kubiëna, W.L. 1955. Animal activity in soils as a decisive factor in establishment of humus forms. In: Soil zoology. Editor: D.K. McE. Kevan. Butterworths, London, United Kingdom. pp. 73-82.

Kuiters, A.T. 1990. Role of phenolic substances from decomposing forest litter in plant-soil interactions. Acta Bot. Neerl. 39: 329-348.

Laverack, M.S. 1961. Tactile and chemical perceptions in earthworms. II. Responses to acid pH solutions. Comp. Biochem. Physiol. 2: 22-34.

Lehmann, R.G., Cheng, H.H., and Harsh, J.B. 1987. Oxidation of phenolic acids by soil iron and manganese oxides. Soil Sci. Soc. Am. J. 51: 352-356.

Macfadyen, A. 1957. Animal ecology. Aims and methods. Pitman, London, United Kingdom.

Mangenot, F., and Toutain, F. 1980. Les litières. In: Actualités d'écologie forestière. Sol, flore, faune. Editor: P. Pesson. Gauthier-Villars, Paris, France. pp. 3-59.

Manil, G., Collin, E., Evrard, R., and Gruber, R. 1953. Les sols forestiers de l'Ardenne. Le plateau de Saint-Hubert-Nassogne. I. Etude pédologique. Bull. Inst. Agron. Stat. Rech. Gembloux 21: 43-68 + addendum

Manil, G., Delecour, F., Forget, G., and El Attar, A. 1963. L'humus, facteur de station dans les hêtraies acidophiles de Belgique. Bull. Inst. Agron. Stat. Rech. Gembloux 31: 1-114.

Melillo, J.M., Aber, J.D., and Muratore, J.F. 1982. Nitrogen and lignin control of hardwood leaf litter decomposition dynamics. Ecology 63: 621-626.

Morgan, C.R., Schindler, S.C., and Mitchell, M.J. 1989. The effects of feeding by Oniscus asellus (Isopoda) on nutrient cycling in an incubated hardwood forest soil. Biol. Fert. Soils 7: 239-246. 
PONGE

Muys, B., and Lust, N. 1992. Inventory of the earthworm communities and the state of litter decomposition in the forests of Flanders, Belgium, and its implications for forest management. Soil Biol. Biochem. 24: 1677-1681.

Perry, D.A., Amaranthus, M.P., Borchers, J.G., Borchers, S.L., and Brainerd, R.E. 1989. Bootstrapping in ecosystems. Bioscience 39: 230-237.

Petersen, H., and Luxton, M. 1982. A comparative analysis of soil fauna populations and their role in decomposition processes. Oikos 39: 287-388.

Piearce, T.G. 1972. The calcium relations of selected Lumbricidae. J. An. Ecol. 41: 167-188.

Ponge, J.F. 1991. Food resources and diets of soil animals in a small area of Scots pine litter. Geoderma 49: 33-62.

Ponge, J.F. 1993. Biocenoses of Collembola in atlantic temperate grass-woodland ecosystems. Pedobiologia 37: 223-244.

Ponge, J.F., and Delhaye, L. 1995. The heterogeneity of humus profiles and earthworm communities in a virgin beech forest. Biol. Fertil. Soils 20: 24-32.

Reichle, D.E., Shanks, M.H., and Crossley, D.A.Jr 1969. Calcium, potassium, and sodium content of forest floor arhtropods. Ann. Ent. Soc. Am. 62: 57-62.

Robinson, C.H., Piearce, T.G., Ineson, P., Dickson, D.A., and Nys, C. 1992. Earthworm communities of limed coniferous soils: field observations and implications for forest management. For. Ecol. Manage. 55: 117-134.

Rodenkirchen, H. 1985. Site diagnosis by phytosociological indication in soil amelioration experiments. In: Abstracts of the First IUFRO Workshop on Qualitative and Quantitative Assessment of Forest Sites with Special Reference to Soil, Birmensdorf, Switzerland, 10/IX-15/IX 1984. Editor: W. Bosshard. Swiss Federal Institute of Forestry Research, Birmensdorf, Switzerland. pp. 24-25. Rohlf, F.J., and Sokal, R.R. 1995. Statistical tables, $3^{\text {rd }}$ edition. Freeman, New York, New York. Rundgren, S. 1994. Earthworms and soil remediation: liming of acidic coniferous forest soils in southern Sweden. Pedobiologia 38: 519-529.

Satchell, J.E., and Lowe, D.G. 1967. Selection of leaf litter by Lumbricus terrestris. In: Progress in soil biology. Editors: O. Graff and J.E. Satchell. Vieweg, Braunschweig, Germany, and North-Holland Publishing Company, Amsterdam, The Netherlands. pp. 102-119. 
PONGE

Schaefer, M. 1991. Fauna of the European temperate deciduous forest. In: Ecosystems of the world. VII. Temperate deciduous forests. Editors: E. Röhrig and B. Ulrich. Elsevier, Amsterdam, The Netherlands. pp. 503-525.

Schaefer, M., and Schauermann, J. 1990. The soil fauna of beech forests : comparison between a mull and a moder soil. Pedobiologia 34: 299-314.

Scheu, S., and Parkinson, D. 1994. Effects of invasion of an aspen forest (Canada) by Dendrobaena octaedra (Lumbricidae) on plant growth. Ecology 75: 2348-2361.

Sokal, R.R., and Rohlf, F.J. 1995. Biometry. The principles and practice of statistics in biological research, $3^{\text {rd }}$ edition. Freeman, New York, New York.

Staaf, H. 1987. Foliage litter turnover and earthworm populations in three beech forests of contrasting soil and vegetation types. Oecologia 72: 58-64.

Sulkava, P., Huhta, V., and Laakso, J. 1996. Impact of soil faunal strucure on decomposition and Nmineralisation in relation to temperature and moisture in forest soil. Pedobiologia 40 : 505-513.

Thill, A., Dethioux, M., and Delecour, F. 1988. Typologie et potentialités forestières des hêtraies naturelles de l'Ardenne Centrale. IRSIA, Brussel, Belgium.

Toutain, F. 1987. Activité biologique des sols, modalités et lithodépendance. Biol. Fert. Soils 3: 31-38.

Toutain, F., Diagne, A., and Le Tacon, F. 1987. Effets d'apports d'éléments minéraux sur le fonctionnement d'un écosystème forestier de l'Est de la France. Rev. Ecol. Biol. Sol 24: 283300.

Toutain, F., and Duchaufour, P. 1970. Etude comparée des bilans biologiques de certains sols de hêtraie. Ann. Sci. Forest. 27: 39-61.

Toutain, F., and Védy, J.C. 1975. Influence de la végétation forestière sur l'humification et la pédogénèse en milieu acide et en climat tempéré. Rev. Ecol. Biol. Sol 12: 375-382.

Turvey, N.D., and Smethurst, P.J. 1985. Variations in wood density of Pinus radiata D. Don across soil types. Can. J. For. Res. 15: 43-49.

Ulrich, B. 1986. Natural and anthropogenic components of soil acidification. Z. Pflanzernaehr. Bodenk. 149: $702-717$

Van der Drift, J. 1962. The soil animals in an oak-wood with different types of humus formation. In: Progress in soil zoology. Editor: P.W. Murphy. Butterworths, London, United Kingdom. pp. 343347. 
PONGE

1 Van der Drift, J. 1963. The disappearance of litter in mull and mor in connection with weather conditions and the activity of the macrofauna. In: Soil organisms. Editors: J. Doeksen and J. Van der Drift. North-Holland Publishing Company, Amsterdam, The Netherlands. pp. 125-133. Van Straalen, N.M., Kraak, M.H.S., and Denneman, C.A.J. 1988. Soil microarthropods as indicators of soil acidification and forest decline in the Veluwe area, the Netherlands. Pedobiologia 32: 47-55.

6 Wolters, V. 1988. Effects of Mesenchytraeus glandulosus (Oligochaeta, Enchytraeidae) on 7 decomposition processes. Pedobiologia 32: 387-398.

8 
1 Table 1. Geographical, vegetation and soil features of the 13 investigated sites. AA =Atlantic Ardenne,

$2 \mathrm{CEA}=$ Centro-Eastern Ardenne. UA = Upper Ardenne. WA $=$ Western Ardenne. Nomenclature of soil 3 types follows FAO-UNESCO classification (Driessen and Dudal 1991).

4 5

6

7 10
Phytosociological type

Elevation

Soil type
Luzulo-Fagetum festucetosum Luzulo-Fagetum festucetosum

Luzulo-Fagetum typicum

Luzulo-Fagetum vaccinietosum $505 \mathrm{~m}$

Luzulo-Fagetum vaccinietosum $445 \mathrm{~m}$

Luzulo-Fagetum typicum

Rienne (WA)

Haut-Fays (AA)

Haut-Fays (AA)

Willerzie (WA)

Houdremont (WA)

Willerzie (WA)

Saint-Hubert (CEA)

307 Saint-Hubert (CEA)
Luzulo-Fagetum typicum

$400 \mathrm{~m}$

Luzulo-Fagetum festucetosum

Luzulo-Fagetum festucetosum

Melico-Fagetum festucetosum

Luzulo-Fagetum vaccinietosum $380 \mathrm{~m}$
Luzulo-Fagetum vaccinietosum $430 \mathrm{~m}$

Luzulo-Fagetum vaccinietosum $385 \mathrm{~m}$
$370 \mathrm{~m}$

$465 \mathrm{~m}$

$500 \mathrm{~m}$

$430 \mathrm{~m}$

$990 \mathrm{~m}$

$375 \mathrm{~m}$

$350 \mathrm{~m}$

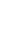

\section{Soil type}

Dystric cambisol
Dystric cambisol
Dystric cambisol
Dystric cambisol
Dystric cambisol
$\quad$ Dystric cambisol
Gleyic cambisol
Dystric cambisol
Leptic podzol
Dystric cambisol
Ferric podzol
Dystric cambisol
Leptic podzol


6

7

Table 2. Coding and methods of recovering used for the different animal groups investigated. MAC = extraction of macrofauna, MES $=$ extraction of mesofauna, MIC $=$ micromorphological dissection. Zoological nomenclature according to Dindal (1990). The methods which have been selected for estimating densities are in bold type.

Code Animal group Method of recovering

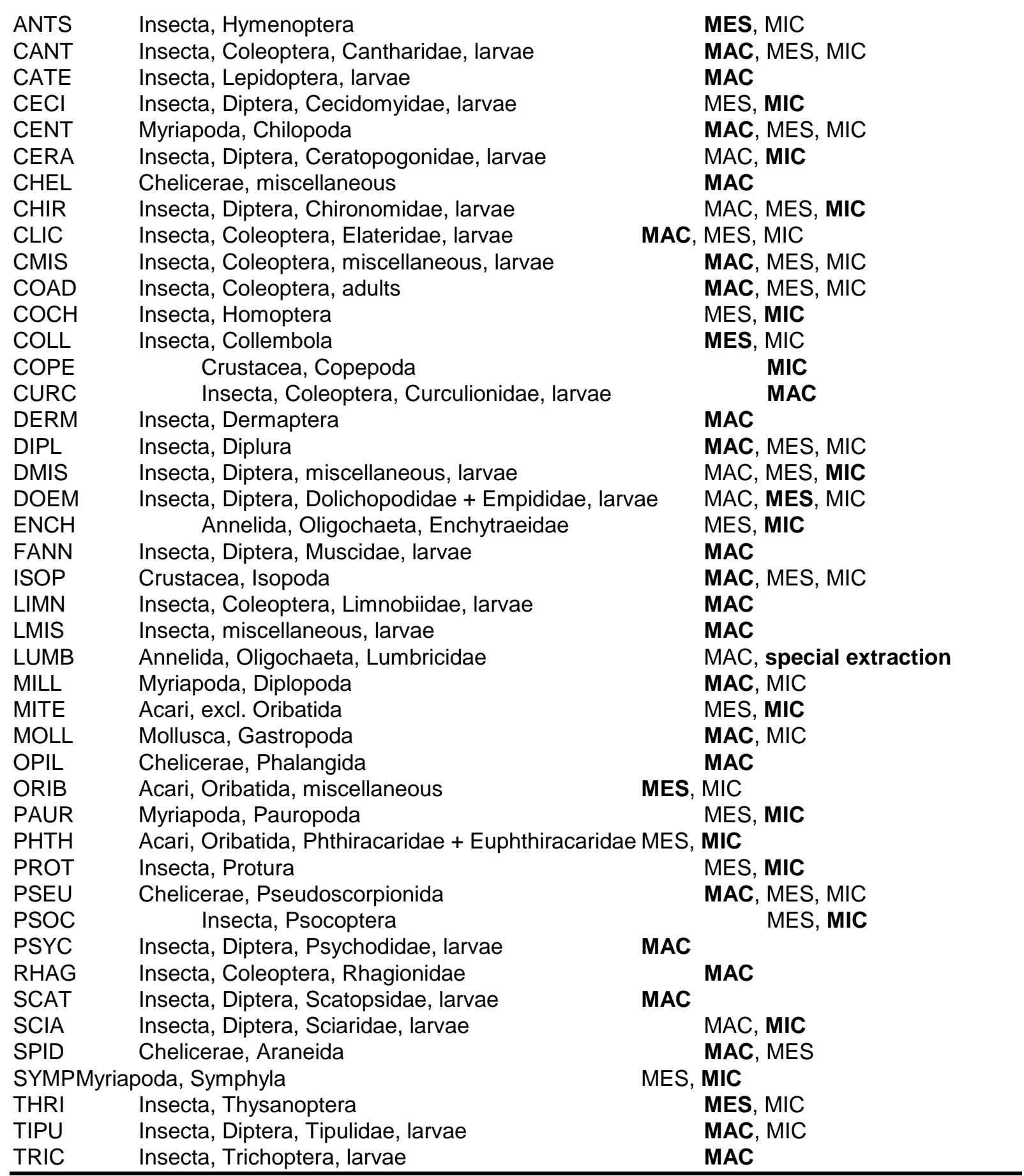


PONGE

1 Table 3. Mean densities. $\mathrm{m}^{-2}$ of zoological groups in the 13 investigated sites, ordinated according to

2 axis 1 of correspondence analysis.

3

4

6

7

8

9

10

11

12

13

14

15

16

17

18

19

20

21

22

23

\section{$\begin{array}{lllllllllllll}100 & 1 & 28 & 3 & 22 & 24 & 17 & 16 & 307 & 5 & 40 & 26 & 4\end{array}$}

\begin{tabular}{|c|c|c|c|c|c|c|c|c|c|c|c|c|c|}
\hline LIMN & 17 & 21 & 6.3 & 0.5 & 2.5 & & 0.5 & & 0.8 & & & & \\
\hline SCAT & 1.6 & 3.1 & 0.9 & 0.5 & & 0.5 & & & & & & & \\
\hline DOEM & 1200 & 160 & 780 & 160 & 26 & 160 & 100 & 100 & 34 & 28 & 3.7 & 5.2 & 5.2 \\
\hline MILL & 54 & 24 & 16 & & 2.2 & & & & & & 2.9 & 2 & \\
\hline TRIC & 0.9 & 1.6 & & & & & & & & & & & \\
\hline CANT & 0.7 & 3.3 & 5.2 & 0.5 & 0.9 & & 0.5 & 0.5 & & & 0.5 & & \\
\hline ISOP & 42 & 0.5 & 2 & & 0.5 & & & & & & 0.5 & & \\
\hline LUMB & 61 & 2 & 0.5 & 1.3 & & & & & 1.6 & & & & \\
\hline PSEU & 17 & 20 & 25 & 10 & 8.3 & 4.8 & 6.7 & 12 & 9.5 & 8.8 & 3.8 & 0.7 & 8.2 \\
\hline RHAG & 6.6 & 24 & 44 & 12 & 16 & 12 & 6 & 8.8 & 1.7 & 7.3 & 5.5 & 0.7 & 1.3 \\
\hline $\mathrm{CHIR}$ & 800 & 570 & 980 & 2500 & 690 & 19 & 44 & 65 & 19 & 1100 & & 34 & \\
\hline MOLL & 6 & & & 0.5 & & & 0.5 & & & & & & \\
\hline FANN & 1.3 & 1.3 & 14 & & 0.5 & 0.5 & 0.5 & & & & 1.6 & 0.7 & \\
\hline CENT & 100 & 99 & 160 & 63 & 21 & 7.8 & 69 & 55 & 20 & 12 & 98 & 54 & 16 \\
\hline OPIL & & 0.5 & 0.5 & & & & 0.5 & & & & & & \\
\hline CHEL & & 5.6 & & & & 0.7 & & & 0.5 & & & & \\
\hline CERA & & & 400 & & & & & & & & & & \\
\hline TIPU & 2.2 & 0.9 & 0.5 & 2.5 & 2.5 & 0.5 & 0.5 & & 0.7 & 1.6 & 1.6 & & 0.5 \\
\hline PROT & & & 1500 & & 19 & 19 & & & & & & & \\
\hline PAUR & 19 & & 5400 & & 27 & 27 & & 44 & 2400 & & & & \\
\hline CECI & 800 & 400 & 48 & & 570 & 27 & 1300 & & 1100 & 27 & 1700 & 19 & 19 \\
\hline CMIS & 34 & 30 & 47 & 37 & 23 & 43 & 32 & 14 & 29 & 39 & 39 & 34 & 25 \\
\hline DERM & & & 1.3 & & & & & & & & & & 0.7 \\
\hline SPID & 11 & 8.6 & 8.7 & 53 & 9.4 & 2.9 & 4.8 & 8 & 19 & 2.3 & 5.5 & 13 & 10 \\
\hline LMIS & & 0.5 & & & & & & & & & & 0.5 & \\
\hline SCIA & 1500 & 1700 & 5800 & 1700 & 65 & 1800 & 3700 & 3900 & 2000 & 19 & 17000 & 980 & 4200 \\
\hline ORIB & 55000 & 150000 & 110000 & 80000 & 43000 & 44000 & 62000 & 94000 & 210000 & 87000 & 72000 & 100000 & 57000 \\
\hline COAD & 15 & 8.9 & 11 & 27 & 5.5 & 22 & 4.4 & 13 & 9.3 & 18 & 17 & 10 & 9.6 \\
\hline COPE & & & 19 & & & & & & 19 & & & & 19 \\
\hline ANTS & & & & & & 28 & & & & & & & \\
\hline DMIS & 19 & 19 & & & & 27 & & 19 & & & 27 & 19 & 39 \\
\hline THRI & & 21 & 4.6 & & 3.7 & & 21 & & 26 & & 3.7 & 3.7 & 21 \\
\hline PSYC & & & & & & & & & & 1.1 & & & \\
\hline PSOC & & & & & & & & & & & & 27 & \\
\hline CATE & & 0.5 & & & & & & & & 0.8 & & 0.5 & 0.5 \\
\hline MITE & 13000 & 18000 & 33000 & 32000 & 19000 & 11000 & 24000 & 38000 & 32000 & 14000 & 29000 & 29000 & 28000 \\
\hline CURC & & & & & & & & & & & & & 0.5 \\
\hline COLL & 42000 & 70000 & 59000 & 88000 & 38000 & 51000 & 57000 & 71000 & 100000 & 68000 & 45000 & 81000 & 120000 \\
\hline $\mathrm{COCH}$ & & & & & & & & & 27 & & 19 & 34 & \\
\hline РHTH & 2900 & 8200 & 20000 & 7300 & 29000 & 5100 & 43000 & 24000 & 33000 & 15000 & 27000 & 9600 & 16000 \\
\hline SYMP & & 400 & & 19 & & 19 & 980 & 39 & 27 & 1100 & 570 & 19 & \\
\hline DIPL & 15 & 0.7 & 97 & 2.9 & 23 & 38 & 87 & 21 & 25 & 36 & 98 & 140 & 50 \\
\hline CLIC & 3.1 & 6.7 & 41 & 81 & 38 & 6.4 & 12 & 20 & 18 & 130 & 120 & 84 & 39 \\
\hline ENCH & & 12000 & 89000 & 100000 & 150000 & 180000 & 170000 & 46000 & 130000 & 79000 & 400000 & 410000 & 380000800000 \\
\hline
\end{tabular}


1 Table 4. Vegetation and soil features of the 13 investigated sites, ordinated according to axis 1 of correspondence analysis.

3

\section{$\begin{array}{lllllllllllll}100 & 1 & 28 & 3 & 22 & 24 & 17 & 16 & 307 & 5 & 40 & 26 & 4\end{array}$}

Elevation $(\mathrm{m})$

$\begin{array}{lllllllllllll}350 & 370 & 375 & 465 & 400 & 390 & 430 & 445 & 380 & 505 & 385 & 430 & 500\end{array}$

Phytosociological type:

Melico-Fagetum festucetosum Luzulo-Fagetum festucetosum Luzulo-Fagetum typicum

Luzulo-Fagetum vaccinietosum

Soil type:

Dystric cambisol

Gleyic cambisol

Leptic podzol

Ferric podzol

Humus form:

Oligomull

Dysmull

Amphimull

Hemimoder

Eumoder

Dysmoder

Height of trees (m)

Litter accumulation index (LAl) $\mathrm{OF}+\mathrm{OH}\left(\mathrm{kg} \cdot \mathrm{m}^{-2}\right)$

Soil analyses (A horizon):

$\mathrm{pH}$ water

$\mathrm{pH} \mathrm{KCl}$

$\mathrm{C} / \mathrm{N}$

Total $\mathrm{Ca}(\%)$

Total Mg (\%)

Total K (\%)

Total $\mathrm{Na}(\%)$

Total iron (\%)

Total manganese (\%)

CEC (meq. $100 \mathrm{~g}^{-1}$ )

Exchangeable $\mathrm{Ca}$ (meq. $100 \mathrm{~g}^{-1}$ )

Exchangeable $\mathrm{Mg}$ (meq. $100 \mathrm{~g}^{-1}$ )

Exchangeable $\mathrm{K}$ (meq. $100 \mathrm{~g}^{-1}$ )

Exchangeable $\mathrm{Na}$ (meq. $100 \mathrm{~g}^{-1}$ )

Litter analyses:

Ashes in total litter (\%)

$\mathrm{N}$ in total litter (\%)

$\mathrm{C} / \mathrm{N}$ in total litter

$\mathrm{Ca}$ in total litter (\%)

Mg in total litter (\%)

$\mathrm{K}$ in total litter (\%)

$\mathrm{Fe}$ in total litter (mg.kg $\left.{ }^{-1}\right)$

Ashes in beech leaf litter (\%)

$\mathrm{N}$ in beech leaf litter (\%)

$\mathrm{C} / \mathrm{N}$ in beech leaf litter (\%)

$\mathrm{Ca}$ in beech leaf litter (\%)

$\mathrm{Mg}$ in beech leaf litter (\%)

$\mathrm{K}$ in beech leaf litter (\%)

$\mathrm{Fe}$ in total litter $\left(\mathrm{mg}^{\mathrm{kg}}{ }^{-1}\right)$
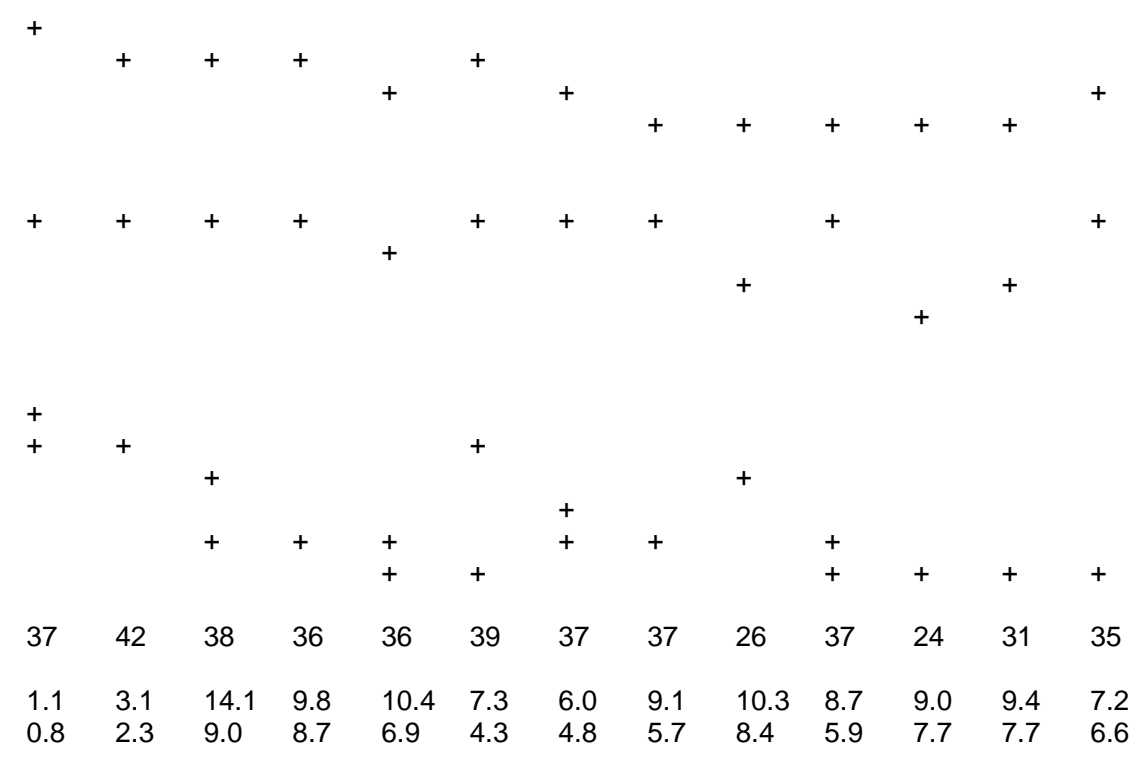

$\begin{array}{lllllllllllll}4.3 & 3.8 & 3.6 & 3.6 & 3.7 & 3.6 & 3.4 & 3.3 & 3.6 & 3.5 & 3.1 & 3.4 & 3.6\end{array}$

$\begin{array}{lllllllllllll}3.6 & 3.1 & 3.0 & 2.8 & 3.1 & 3.0 & 2.7 & 2.6 & 2.8 & 2.9 & 2.0 & 2.5 & 2.9\end{array}$

$\begin{array}{lllllllllllll}14.5 & 14.2 & 14.9 & 16.6 & 16.5 & 16.6 & 18.3 & 18.9 & 19.5 & 17.4 & 19.8 & 18.9 & 17.8\end{array}$

$\begin{array}{lllllllllllll}0.19 & 0.11 & 0.02 & 0.03 & 0.05 & 0.04 & 0.10 & 0.09 & 0.02 & 0.11 & 0.06 & 0.04 & 0.02\end{array}$

$\begin{array}{llllllllllllll}0.12 & 0.10 & 1.17 & 0.11 & 0.24 & 0.18 & 0.11 & 0.11 & 0.11 & 0.13 & 0.04 & 0.11 & 0.19\end{array}$

$\begin{array}{lllllllllllll}0.25 & 0.21 & 0.21 & 0.25 & 0.24 & 0.25 & 0.23 & 0.24 & 0.30 & 0.26 & 0.13 & 0.23 & 0.28\end{array}$

$\begin{array}{lllllllllllll}0.08 & 0.11 & 0.06 & 0.11 & 0.07 & 0.09 & 0.11 & 0.19 & 0.07 & 0.12 & 0.05 & 0.08 & 0.10\end{array}$

$\begin{array}{lllllllllllll}8.0 & 8.6 & 10.2 & 9.1 & 4.9 & 5.4 & 4.6 & 5.5 & 7.9 & 9.4 & 1.4 & 4.8 & 6.9\end{array}$

$\begin{array}{lllllllllllll}0.24 & 0.16 & 0.15 & 0.11 & 0.04 & 0.08 & 0.02 & 0.01 & 0.11 & 0.07 & 0.00 & 0.01 & 0.04\end{array}$

$\begin{array}{lllllllllllll}13.1 & 7.5 & 11.1 & 10.6 & 10.2 & 10.6 & 15.2 & 16.1 & 8.6 & 9.1 & 21.4 & 15.0 & 13.0\end{array}$

$\begin{array}{lllllllllllll}3.48 & 0.25 & 0.29 & 0.72 & 0.22 & 0.14 & 0.98 & 0.26 & 0.11 & 0.09 & 0.86 & 0.36 & 0.30\end{array}$

$\begin{array}{lllllllllllll}0.61 & 0.17 & 0.33 & 0.21 & 0.16 & 0.15 & 0.39 & 0.29 & 0.25 & 0.13 & 0.69 & 0.30 & 0.29\end{array}$

$\begin{array}{lllllllllllll}0.44 & 0.25 & 0.23 & 0.34 & 0.29 & 0.24 & 0.46 & 0.31 & 0.31 & 0.18 & 0.57 & 0.35 & 0.32\end{array}$

$\begin{array}{lllllllllllll}0.13 & 0.07 & 0.08 & 0.06 & 0.05 & 0.07 & 0.10 & 0.12 & 0.11 & 0.08 & 0.19 & 0.14 & 0.10\end{array}$

$\begin{array}{lllllllllllll}6.7 & 5.4 & 3.9 & 3.7 & 4.2 & 4.0 & 3.6 & 3.1 & 4.2 & 2.9 & 3.7 & 2.7 & 3.2\end{array}$

$\begin{array}{lllllllllllll}1.4 & 1.6 & 1.6 & 1.7 & 1.5 & 1.5 & 2.0 & 1.4 & 1.1 & 1.4 & 1.7 & 1.5 & 2.2\end{array}$

$\begin{array}{lllllllllllll}31.9 & 24.3 & 30.5 & 31.0 & 32.4 & 36.7 & 27.4 & 32.4 & 44.7 & 36.4 & 29.5 & 36.0 & 24.0\end{array}$

$\begin{array}{llllllllllllll}1.22 & 0.60 & 0.52 & 0.44 & 0.42 & 0.45 & 0.44 & 0.37 & 0.50 & 0.39 & 0.55 & 0.37 & 0.42\end{array}$

$\begin{array}{lllllllllllll}0.14 & 0.06 & 0.08 & 0.04 & 0.05 & 0.05 & 0.06 & 0.05 & 0.07 & 0.05 & 0.08 & 0.05 & 0.06\end{array}$

$\begin{array}{lllllllllllll}0.32 & 0.31 & 0.21 & 0.32 & 0.27 & 0.30 & 0.52 & 0.26 & 0.34 & 0.33 & 0.42 & 0.31 & 0.31\end{array}$

$\begin{array}{lllllllllllll}930 & 1100 & 540 & 390 & 610 & 520 & 540 & 440 & 560 & 310 & 330 & 220 & 350\end{array}$

$\begin{array}{lllllllllllll}8.2 & 5.0 & 4.3 & 4.5 & 4.7 & 4.7 & 4.0 & 3.3 & 4.4 & 3.2 & 4.1 & 3.3 & 3.8\end{array}$

$\begin{array}{lllllllllllll}1.4 & 1.6 & 1.6 & 1.7 & 1.5 & 1.5 & 2.0 & 1.4 & 1.1 & 1.4 & 1.8 & 1.6 & 1.5\end{array}$

$\begin{array}{lllllllllllll}29.8 & 27.6 & 29.8 & 26.2 & 30.1 & 31.5 & 23.3 & 31.8 & 38.9 & 34.1 & 25.5 & 30.5 & 29.8\end{array}$

$\begin{array}{lllllllllllll}1.84 & 0.72 & 0.62 & 0.56 & 0.58 & 0.60 & 0.50 & 0.41 & 0.68 & 0.51 & 0.63 & 0.46 & 0.54\end{array}$

$\begin{array}{lllllllllllll}0.18 & 0.05 & 0.08 & 0.04 & 0.04 & 0.04 & 0.05 & 0.04 & 0.07 & 0.04 & 0.07 & 0.05 & 0.05\end{array}$

$\begin{array}{lllllllllllll}0.22 & 0.2 & 0.14 & 0.21 & 0.14 & 0.18 & 0.36 & 0.15 & 0.22 & 0.19 & 0.39 & 0.25 & 0.18\end{array}$

$\begin{array}{lllllllllllll}730 & 640 & 540 & 470 & 430 & 530 & 530 & 420 & 410 & 330 & 310 & 250 & 360\end{array}$ 
PONGE

\section{$1 \quad$ Legends of figures}

2

Fig. 1. Ordination of sites (13) and zoological groups (44), used as main variates, according to their coordinates along axis 1 of correspondence analysis. Coding of sites and zoological groups according to Tables 1 and 2, respectively. The position of the origin is indicated by an arrow. Codes for zoological groups belonging to macrofauna are in bold type. Variates significantly correlated with axis 1 coordinates were indicated by rectangular bordering.

Fig. 2. Ordination of sites (13) and some additional variates (elevation, humus forms, soil types, phytosociological types), according to their coordinates along axis 1 of correspondence analysis. Variates significantly correlated with axis 1 coordinates were indicated by rectangular bordering.

Fig. 3. Ordination of sites (13) and some additional variates $(\mathrm{pH}$ and $\mathrm{C} / \mathrm{N}$ ratio in the $\mathrm{A}$ horizon, litter accumulation, height of trees) according to their coordinates along axis 1 of correspondence analysis. Variates significantly correlated with axis 1 coordinates were indicated by rectangular bordering.

Fig. 4. Ordination of sites (13) and some additional variates (exchangeable and total bases in the A horizon) according to their coordinates along axis 1 of correspondence analysis. Variates significantly correlated with axis 1 coordinates were indicated by rectangular bordering. Plus or minus sign means higher or lower values, respectively.

Fig. 5. Ordination of sites (13) and some additional variates (mineral content of litter) according to their coordinates along axis 1 of correspondence analysis. Variates significantly correlated with axis 1 coordinates were indicated by rectangular bordering. Plus or minus sign means higher or lower values, respectively. 
PONGE

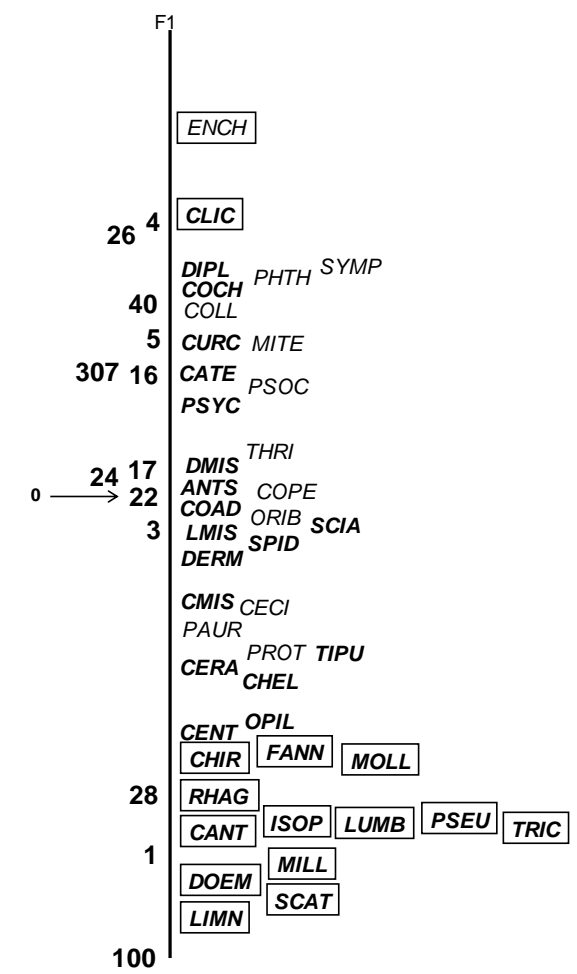

Fig. 1

3 
PONGE

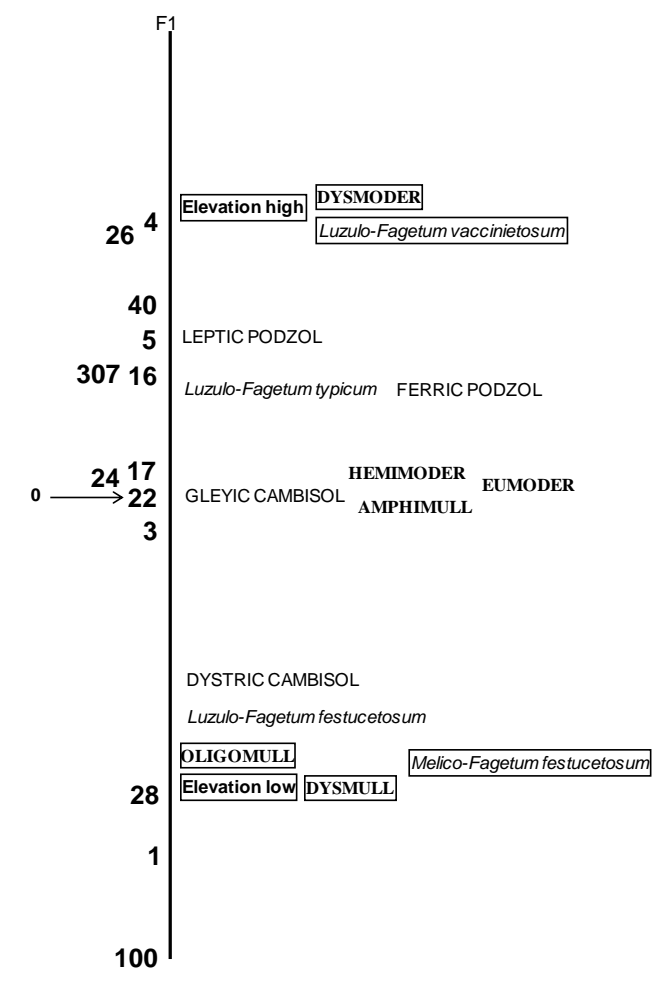

Fig. 2

3 
PONGE

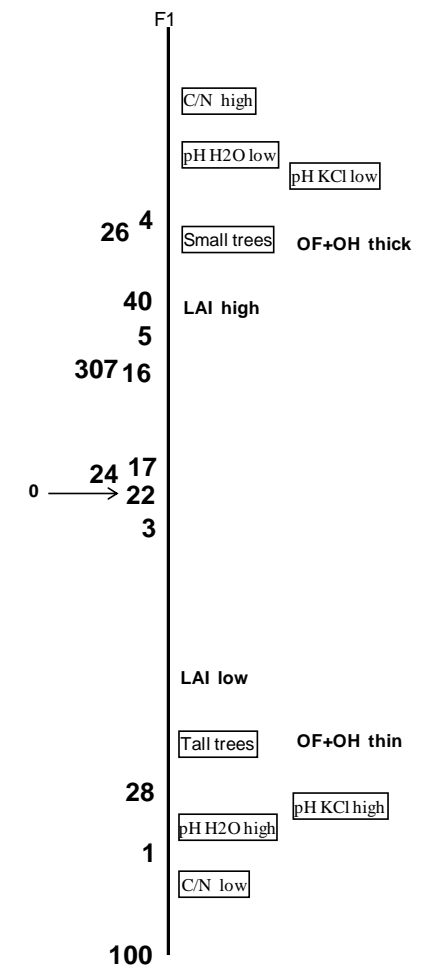

Fig. 3

3 
PONGE

1

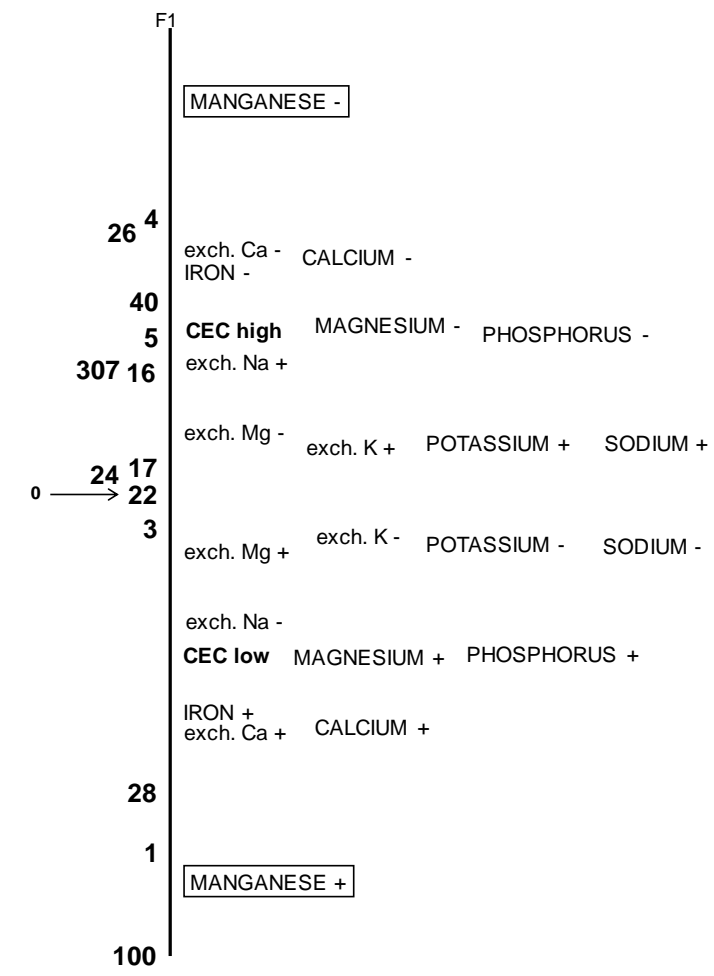

Fig. 4

3 
PONGE

1

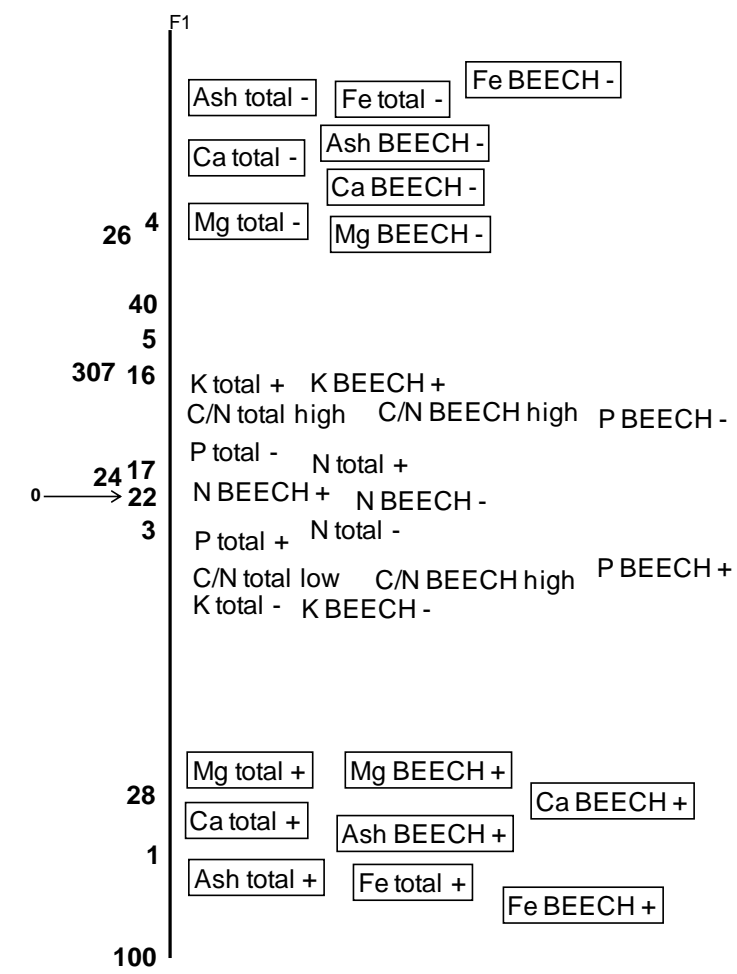

Fig. 5 